\title{
The Evolution Of Employment-At-Will: Past, Present, And Future Predictions
}

\author{
Jane Whitney Gibson, Nova Southeastern University, USA
}

Lester Lindley, Nova Southeastern University, USA

\begin{abstract}
This article examines the origins and evolution of employment-at-will, investigates judicially created at-will exceptions and statutory limitations today, and suggests that employment-at-will is slowly evolving into a just cause standard. The authors recommend an employment policy that both adheres to the law and promotes an atmosphere of fair employment practices that coincide with American values of fair play.
\end{abstract}

Keywords: Employment-at-will, just cause, at-will exceptions

\section{INTRODUCTION}

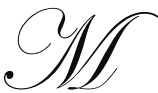

anagers and employees alike seem to have misconceptions about the definition and legal implications of "employment-at-will." When mid-career, executive MBA students were questioned about their understanding of this policy, they all acknowledged hearing of employment-at-will and most felt sure they understood how it worked. Some, however, felt that only some states had employment-at-will laws while others confused these laws with right-to-work legislation. When questioned about how employment-at-will actually worked, some felt that such laws gave employers a free rein in firing employees at will while others believed that employment-at-will has been eroded over time by wrongful discharge lawsuits. Empirical studies have shown that about $80-90 \%$ of employees believe that employers are obliged to be fair in their employment decisions and that they "have an obligation to reciprocate," i.e., the great majority of employees erroneously think they are working under conditions of "just cause." (Dannin, 2007).

In actuality, employment-at-will is the law in every state of the union although state-by-state exceptions are responsible for a wide variety of interpretations and applications of the law. As long as related employment laws such as equal opportunity legislation are not being broken, all private sector employees not covered by a union contract or some other type of formal contract may be discharged for good cause, bad cause, or no cause. (Sentell \& Robbins, 2008). Thus, an employee cannot be fired because she is black, but "she can be fired for wearing a hairstyle that the employer doesn't like." (Suk, 2007, p. 75)

The purpose of this article is to examine the origins and evolution of employment-at-will, investigate the judicially created at-will exceptions and statutory limitations today, and consider likely trends of employment-atwill for the near future. It is important that managers and human resources professionals understand the law today and track the evolving trends so that they may be both effective and efficient in handling employment issues related to employment-at-will. The authors further recommend an employment policy that will both adhere to the law and promote an atmosphere of fair employment practices that seem to coincide with American values of fair play.

\section{HISTORICAL OVERVIEW}

Early in our history, the employment relationship was governed by both "entire contracts" and "employment-at-will." In spite of their significant differences, entire contracts, a variant of English employment contracts, the "American Rule" of employment-at-will, and the evolution of exceptions to at-will employment register a common concern which deals with the duration of employment contracts or expectations. Throughout the American experience, before and after Independence, at-will employment was the dominant legal doctrine that 
governed the duration of employment contracts. Entire contracts, a carryover from English law, played a subordinate role in pre-Civil War America. (Bellam, 1995-1996; Schmidt, 1998).

Typically an entire contract required employees, historically known as "servants," to serve a full year before their employer owed them any portion of their wages. Quitting work before the end of the year's service meant the worker earned no income for the work completed. Employees who failed to complete fully their contract in its entirety forfeited all benefits under the contract. At-will departed significantly from entirety. An 1884 Tennessee case stated the at-will rule in stark terms when it ruled that employers could "discharge or retain employees at will for good cause or for no cause, or even for bad cause, without thereby being guilty of an unlawful act per se." (Payne v. Western, 1884, pp. 519-520) During the nineteenth century, entire contracts played a minor role in determining the duration of employment contracts in pre-Civil War America. However, employment at-will was the dominant legal doctrine that governed their duration.

Whether entire contracts or at-will, courts enforced them. For example, an employee in Massachusetts left his employment before the contract's term expired and tried to recover wages proportional to the time he served. The court found it "repugnant to the well established rules" of "civil jurisprudence" and "the dictates of moral sense, that a party who deliberately and understandably enters into an engagement and voluntarily breaks it, should be permitted to make that very engagement the foundation of a claim to compensation for services under it." (Stark v. Parker, 1824, p. 271). However, in their enforcement of entire contracts, courts not only found for employers, but also for employees. Courts awarded damages to employees whose abusive employers provoked them to leave early or terminated their employment prior to the contract's terms. For example, in 1871, a Michigan appellate court sustained the trial court's finding that the parties to a dispute had an entire contract and awarded the plaintiff damages after his employer discharged him after completing eight months into a year's contract. (Franklin Mining $v$ Harris, 1871; Ballam, 1995-1996; Ballam, 1996).

As pronounced as the durational differences were in the two forms of employment contracts, courts found that contractual mutuality or, put differently, contractual reciprocity provided compelling similarities. Mutuality, the heart of contract, trumped the durational differences. Entire contracts assured the parties that each had rights and duties for an entire year. Each voluntarily agreed to the contract and each could make plans and judgments based on their reciprocal obligations for the upcoming year. By way of contrast, a different calculus characterized the contractual reciprocity in at-will contracts. The employer's right to discharge a worker at will, without cause, balanced the right of employees to quit at any time. For example, a Tennessee court affirmed that employees had the right to quit, which they could "exercise in the same way, to the same extent, for the same cause or want of cause as the employer." (Payne v. Western, 1884, pp. 520-521).

Entrenched as it was in American employment law, critics began an assault on at-will beginning in the 1960s. In a frequently quoted 1967 article against at-will, Lawrence Blades argued that employer power in an at-will system threatened individual freedom. He observed that it was difficult to define "the scope of the employer's appropriate control" since it is difficult to distinguish "the reasonable demands of an employer ... from those which are overreaching." (Blades, 1967, p. 1406). Blades further argued that existing employee protections were not adequate and that failure to bend to the employer's whim could put the employee's livelihood in jeopardy. Professionals might find themselves caught between violating their codes of ethics and preserving their daily bread. $\mathrm{He}$ feared abusive use of power and felt the law should confront the problem. Since existing protections and remedies were inadequate, Blades concluded:

An appropriate legal response would be to confer on the afflicted employee a personal remedy for any damages he suffers when discharged as a result of his employer's attempt to intimidate or coerce him in a way which bears no reasonable relationship to the employment. For convenience, a discharge so motivated might be termed an "abusive" discharge. (Blades, 1967, p. 1413).

The standards that Blades urged would put at-will employees on par with union members. Union members generally had clauses that required just cause for their termination. Limited statutory protection might protect against some employer abuse, but courts had begun to recognize that employees had personal remedies against abuse, independent of union contracts or statutory enactments. Courts created at-will, so it seemed logical that 
courts might modify it, but they did so slowly on a case-by-case basis. While most courts joined the trend in the 1970s, and especially in the 1980s, several courts concluded that at-will changes were a legislative, not judicial function. However, beginning in the 1959, courts began creating three major judicial exceptions to at-will: dismissals of employees on grounds that violate public policy, assurances that employees have through implied contracts, and covenants of good faith and fair dealing in employment contracts and the employment setting. (Walsh \& Schwartz, 1996; Muhl, 2001).

\section{EMPLOYMENT-AT-WILL TODAY}

Undeniably, employment-at-will is the law of the land in the United States today. What constitutes legal reason for termination?

Just about everything. Employers can fire workers for failing to do their assigned task in a timely manner, for being insubordinate, even for associating with people the employer doesn't like. For example, if two co-workers are friends outside of the office and one of them gets fired, the other worker also could get fired by the employer just because the two workers remained friends. (Gorczyca, 2006, p. 19)

All fifty states honor at-will and all but Florida, Georgia, Louisiana and Rhode Island have exceptions to the at-will doctrine. These widespread exceptions preclude HR departments from knowing conclusively what atwill means in terms of their own policies and procedures. Interpretation of the law varies widely from state to state and for companies doing business in multiple states, those variations can be confusing at best and liability traps at worst. Table 1 shows which states recognize the three major exceptions to employment-at-will. Each exception is distinctive and important as it impacts on the concept of employment-at-will.

\section{The Public Policy Exception}

Upheld by 42 states and the District of Columbia, the public policy exception is the most common modification to the at-will doctrine. Basically, it holds that if the dismissal contradicts state or federal public policy, the courts will not uphold it. (Proffitt, 2009). "When an employee is discharged for a reason or in a manner that contravenes some clearly defined and fundamental public policy, the employer may be held legally liable." (Cavico, 1992, p. 503). A California appellate court established the ground work for this exception in a 1959 case in which the employer, a labor union, discharged one of its employees for refusing to commit perjury. The employee had excellent performance ratings until he "testified truthfully before a legislative hearing, contrary to the union's instructions." (Petermann v. International Brotherhood, 1959, p. 28). Since perjury is against the public policy, the court found for the employee.

Public policies can be found in state constitutions or statutes and include such things as not allowing an employee to be terminated for filing a workers' compensation claim (Sentell \& Robbins, 2008). Other common bases of wrongful discharge suits under the public policy exception include protection against whistleblowing, and refusing to commit an illegal act. (Lichtenstein \& Darrow, 2008). Generally, plaintiffs had to prove the state had specific statutes or policies that protected them from wrongful discharge. For example, workers' compensation acts provided recovery for work-related injuries. Workers discharged for filing claims generally prevailed in instances where they were fired because of filing these claims. Likewise, courts usually found for employees who were discharged for jury duty. Warns the Mississippi Supreme Court, "In this day and age, the decision to take an adverse personnel decision must be made only after proper procedures have been followed, proper warnings administered, and full documentation obtained." (Sentell \& Robbins, 2008, p. 14)

\section{The Implied Contract Exception}

Employment manuals and assurances to employees that convey the impression that continued employment is contingent on good performance is the most common basis for the implied contract limitation. This is particularly true when the employee has given years of service and received regular promotions. Employees can use handbooks, performance evaluations, oral assurances of continued employment from their supervisors and the company's history to demonstrate the existence of an implied contract. A California ruling affords an example. The employee had assurances from the company's president that "if you are loyal to [the company] your future is secure." (Pugh

v. See's Candies, 1982, p. 311). Some years later he was discharged, but given his history with the company, 
assurances made to him and the absence of any adverse disciplinary problems, the court found for him. As of mid2009, thirty-seven states found implied contracts imposed limits on at-will.

Table 1: Employment at Will Exceptions by State (June 2009)

\begin{tabular}{|c|c|c|c|}
\hline State & Public Policy & Implied Contract & Good Faith Fair Deal \\
\hline Alabama & No & Yes & Yes \\
\hline Alaska & Yes & Yes & Yes \\
\hline Arizona & Yes & No & No \\
\hline Arkansas & Yes & Yes & No \\
\hline California & Yes & Yes & Yes \\
\hline Colorado & Yes & Yes & No \\
\hline Connecticut & Yes & Yes & No \\
\hline Delaware & Yes & No & Yes \\
\hline District of Columbia & Yes & Yes & No \\
\hline Florida & No & No & No \\
\hline Georgia & No & No & No \\
\hline Hawaii & Yes & Yes & No \\
\hline Idaho & Yes & Yes & Yes \\
\hline Illinois & Yes & Yes & No \\
\hline Indiana & Yes & No & No \\
\hline Iowa & Yes & Yes & No \\
\hline Kansas & Yes & Yes & No \\
\hline Kentucky & Yes & Yes & No \\
\hline Louisiana & No & No & No \\
\hline Maine & No & Yes & No \\
\hline Maryland & Yes & Yes & No \\
\hline Massachusetts & Yes & No & Yes \\
\hline Michigan & Yes & Yes & No \\
\hline Minnesota & Yes & Yes & No \\
\hline Mississippi & Yes & Yes & No \\
\hline Missouri & Yes & No & No \\
\hline Montana & Yes & No & Yes \\
\hline Nebraska & No & Yes & No \\
\hline Nevada & Yes & Yes & Yes \\
\hline New Hampshire & Yes & Yes & No \\
\hline New Jersey & Yes & Yes & No \\
\hline New Mexico & Yes & Yes & No \\
\hline New York & No & Yes & No \\
\hline North Carolina & Yes & No & No \\
\hline North Dakota & Yes & Yes & No \\
\hline Ohio & Yes & Yes & No \\
\hline Oklahoma & Yes & Yes & No \\
\hline Oregon & Yes & Yes & No \\
\hline Pennsylvania & Yes & No & No \\
\hline Rhode Island & No & No & No \\
\hline South Carolina & Yes & Yes & No \\
\hline South Dakota & Yes & Yes & No \\
\hline Tennessee & Yes & Yes & No \\
\hline Texas & Yes & No & No \\
\hline Utah & Yes & Yes & Yes \\
\hline Vermont & Yes & Yes & No \\
\hline Virginia & Yes & No & No \\
\hline Washington & Yes & Yes & No \\
\hline West Virginia & Yes & Yes & No \\
\hline Wisconsin & Yes & Yes & No \\
\hline Wyoming & Yes & Yes & Yes \\
\hline Totals & 43 & 37 & 10 \\
\hline
\end{tabular}

Source for the table: Walsh and Schwarz, (Summer 1996); Muhl, (January 2001); Abraham, (2008). 


\section{The Good Faith and Fair Dealing Exception}

Of the three judicially-created exceptions to at-will, ten states found for discharged employees on grounds their employers violated the covenant of good faith and fair dealing. The covenant is inherent in all common law contracts, so courts that use it as an exception to at-will "emphasize continuity with contract principles." (Walsh \& Schwarz, 1996, p. 669) For example, an Arizona court ruled that "we do not feel that we should treat employment contracts as a special type of agreement in which the law refused to imply the covenant of good faith and fair dealing in all other contracts." (Wagenseller v. Scottsdale Memorial Hospital, 1985, p. 740).

Two years earlier, the Alaska Supreme Court found for an employee on grounds of the breach of the covenant when, "After 16 years of work, the employers terminated the employee when he tried to enforce the portion of the employment contract regarding sharing profits." The court found that "the employee's employment contract contained an implied covenant of good faith and fair dealing" and noted that "good faith and fair dealing in this case would prohibit firing [the employee] for the purpose of preventing him from sharing in future profits ... The circumstances surrounding [his] termination give rise to an inference that he was fired for that reason." (Mitford v. deLasala, 1983, p. 1031)

Without specifically using the term, a recent summary of the covenant of good faith and fair dealing implied that the covenant rests squarely on contractual mutuality. It noted that "In every employment relationship, there is a duty of good faith and fair dealing - even in at-will employment relationships. Employees have a duty of loyalty to the company and employers have a duty to comply with the terms of the contract in good faith." (Center For Education \& Employment Law, 2009, p. 168)

\section{Other Exceptions}

In addition to the direct exceptions noted above, there are other laws that supersede the at-will doctrine. For example, equal employment legislation makes it illegal to discriminate against any employee based on race, sex, age, ethnic background, religion, or disability. Employers who terminate an employee under the at-will doctrine often find themselves involved in a court case because of alleged discrimination. Additionally, state and federal courts can hear cases of termination related to wage and hour issues, or retaliation based on OSHA reports or FMLA leave-taking. (Lynott, 2008).

At least two states, Montana, 1987, and Arizona, 1996, have modified the judicially created at-will doctrine and its exceptions by statutory enactment. The Arizona statute restores at-will, with the only exception being the public policy exception, strictly construed. Montana's Wrongful Discharge from Employment Act of 1987 recognizes employment at will but spells out the legal basis for a wrongful discharge suit. (Proffitt, 1987). The Montana enactment restores at-will except for violation of public policy and discharge not for "good cause" after the employee completed the employer's "probationary period." By 2007, 22 states made it unlawful to dismiss an employee in retaliation for filing a workers' compensation claim and 34 had given legislative protection to whistleblowers. (Stone, 2007)

Still other exceptions exist as various courts,

...have allowed employees to recover against employers in discharge situations under theories of wrongful discharge, intentional infliction of emotional distress, defamation, and implied covenant of good faith and fair dealing, among others. (Zachary, 2008, p. 23)

Further, Puerto Rico and the Virgin Islands have "just cause" laws. In Colorado, workers have a "rebuttal presumption" where if an employee works for an indefinite period without a contract, he or she is thought to have rights against termination. South Dakota statute says that a yearly salary presumes employment is for a year and termination before the end of the year requires employers to have grounds for the termination. (Anonymous, 2007) 


\section{A LOOK TO THE FUTURE AND A POSSIBLE NATIONAL JUST CAUSE STANDARD}

Over the past few decades, exceptions to at-will contracts, the nature of those exceptions, their legitimacy, and the future of at-will generated several hundred law review articles. Concerns persist about the duration of employment contracts and their legitimate termination. The absence of clear, predictable standards that distinguish between lawful and wrongful discharge perplexes employers, employees, attorneys and courts alike. While courts and legal commentators have not specifically addressed the prospect of national legislation to replace at-will with the predictability of a just cause standard, the ground work for serious consideration of such a standard in the nearfuture exists. As recently as 2008, Amendment 55, designed to require employers to establish a just cause in Colorado showed that there is serious public concern about the appropriateness of at-will as a guiding employment principle. (Benjes \& MacDonald, 2008). Just a month before the election, the amendment was pulled off the ballot in a deal with business leaders to throw their support against a right-to-work amendment. Among other criticisms of at-will, four major concerns augur well for changes of its current status. These include (1) mutuality/fairness, (2) burden of proof issues, (3) economic issues, and (4) the undermining of the predictability of the law.

\section{Mutuality/Fairness: The Sham of Reciprocity}

Mutuality has "the appeal of symmetry," since the employer's right to fire balances the employee's right to quit. (Blades, 1967, p. 1426). Perhaps Andrew Carnegie expressed the idea best in 1886, when he wrote that labor's struggle about oppression, from the "serfdom of the past" had undergone a "revolution." The poorest laborer, he continued, who "can handle a pick or a shovel, stand upon equal terms with the purchaser of his labor ... He negotiates and thus rises to the dignity of an independent contractor." (Carnegie, 1886). Even the Tennessee court that gave at-will its classic formulation knew better when it conceded that employers had superior bargaining power. It noted that employers, including "Great corporations, strong associations and wealthy individuals may thus do great mischief and wrong ... and thus greatly injure individuals and the public," but the law could not "set bound[s] to it unless it is exercised illegally." (Payne v. Western, 1884, pp. 529-21).

Critics of at-will argue that the apparent symmetry is a "hollow" notion, a remnant from the distant past. "We may speedily discard any lingering notion that contract is not an instrument of power," a Northwestern University contracts scholar wrote. "Plainly it is. The donkey who is offered the carrot has no real choice unless he is well-fed or has other means of nourishment available." (Havighurst, 1961, 38). The analogy is clear: since "We have become a nation of employees," who depend upon others for their livelihood, few have other means of supporting themselves or their families. (Cited in Blades, 1967, p. 1404). There is little to no symmetry between employers who fire on a whim compared to an employee quitting. A comparable power imbalance undermines mutuality from another perspective.

In its classic application, at-will begins and ends with specific times. Prior to employment, neither party owed the other any obligations; once the employee quits or is dismissed, in a true at-will contract the obligations cease. However, in recent decades courts enforce "employer-imposed terms" beyond the contract's life. "Imposed terms" of arbitration clauses and post-employment restrictive covenants, survive beyond the life of the contract. (Stone, 2007, p. 91). Courts generally enforce restrictions as long as the employer wants, but in all other respects, the employment is at-will. These clauses conflict with fundamental assumptions of at-will that neither party owes the other further duties when the employment ceases. The purported mutuality of at-will distorts reciprocity since employees continue to owe without any comparable duty owed to employees. Little wonder that one commentator referred to mutuality in at-will "illusory at best," an "anachronistic doctrine" that destroys even the appearance of reciprocity. (Cottone, 2002, pp. $1259 \& 1261$ ).

\section{Burden of Proof Issues}

Burden of proof issues create major, often impossible challenges for employees and debase longestablished labor and civil rights legislation. While at-will is the American default rule for most employees, the rule "swallows" the exceptions. (Slater, 2007). Employers cannot discharge employees if the discharge violates any of the exceptions to the rule. However, courts rule that discharged employees must prove that their employer dismissed them for an illegal reason. Instead of employers proving removal for just cause, courts shift the burden to 
employees, who must prove they were discharged for an illegal reason. This burden-shifting tends to subvert key areas of American law, in addition to swallowing at-will exceptions. Courts, including the U.S. Supreme Court have adopted the same burden-shifting technique, which seriously undermines major Civil Rights legislation and national labor law. Employers cannot fire employees because of race, sex, religion, or national origin, but can discharge them for:

...other than a legally prohibited reason. Employees have the burden of proof to show that illegal discrimination motivated the employer, and under at-will doctrine, it is legal for employers to fire employees for any number of reasons, including the morally and intellectually indefensible, the petty, and the illogical." (Slater, 2007, p. 59)

Litigants cannot bar prospective jurors because of race, but can for any other reason, even using the at-will standard, for no reason at all. Employers cannot discriminate against employees for their union activities, but can for other reasons, even without stating those other reasons. (Slater, 2007.) The opportunities for abuse are obvious.

Fundamental American laws, including constitutional protections, afford citizens a broad spectrum of rights. However applying the at-will standard of proving improper motivation to violations, whether real or imagined, to the most important legal protections citizens enjoy are compromised and often destroyed, all with the sanction of the nation's legal system. (Slater, 2007). The employer "controls all the documents and witnesses and has been trained to be cautious in its statements and diligent in documenting employees' shortcomings." (Gertz, 2008, pp. 496-97). By comparison employees have to divine employer motivation, without access to documents and witnesses. Ironically, if not tragically, the nearly impossible burden of proof standard that swallows many at-will exceptions, debase basic American rights, even rights protected by legislative enactments and the Constitution. (Slater, 2007; Moss, 2005-2006).

\section{Economic Issues Confound At-Will Rationale}

Longevity of at-will seems to be a rationale courts use in upholding at-will. A 2002 Wisconsin Supreme Court ruling noted that at-will "is a 'stable fixture' of our common law ..." Going further the court found at-will to be "central to the free market economy and 'serves the interests of employees as well as employers' by maximizing the freedom of both ..." (Cited in Dannin, 2007, p. 6). As lofty as the idea of maximizing the freedom of employers and employers, there is no evidence that at-will serves the market place. The erosion of the doctrine since the 1960s and the genuine efforts to calibrate and apply those exceptions in specific, concrete settings comes at a high, if not exorbitant costs to employers and employees, "and employers are paying a large part of that price." (Dannin, 2007, p. 6).

Even with the rising litigation fears that employers have from product liability, patent infringement claims to "contentious shareholder revolts," the "greatest single dispute angst among U.S. companies stems from labor and employment problems." (Danin, 2007, p. 7). Even when management prevails, the cost in time, energy and money is disruptive to good company management. Another careful student of the issue cautions employers to avoid being "a Sitting Duck." He notes that juries awards for wrongful discharge range from "six, seven and occasionally eight figures." (Atwood, 1991, p. 96.) Employees fare no better under at-will.

It's common place that Americans generally describe themselves and define their role by their work. The employee's work and the benefits that it affords define the limits and possibilities for his or her family, for their standard of living and non-economic roles in society. (Peck, 1991, 719). At-will is inconsistent with societal expectations "when it has the effect of insulating from legal challenge an employer who fires a worker for reporting or refusing to participate in unethical or illegal activity." (Callahan, 2002, 481). Little wonder that improving employment prospects was a central feature of the New Deal and much of American policy since the end of World War II. (Shales, 2007; Employment Act of 1946). Perhaps an apt description for any dismissal and especially wrongful or abusive discharge is that it's "a kind of organizational equivalent of capital punishment." (Cited in Blades, 1967, p. 1406.) Students of the issue estimate that between 200,000, and maybe even upwards of 300,000 employees suffer the "organizational capital punishment[s]" annually. Another study concluded that using standards for discharging unionized workers applied to at-will employees, "there would be as many as 300,000 claims of unjust discharge" annually. (Peck, 1991, pp. 730-31). 
Employers who clearly explain handbook provisions that the employment is at-will fare no better. Careful managerial explanations assure employee understanding of at-will while often undermining employee morale. After a survey to learn of employee reaction to at-will provisions, employees said they "had been happy about starting their jobs until they read the handbook. After that, they felt less attachment and enthusiasm." Law students and lawyers who didn't practice employment law "all reacted negatively." The upshot: one of the costs of at-will is the "alienation of employees, in particular, good employees." (Dannin, 2007, p. 12). It is impossible to argue with the conclusion that at-will and its exceptions are experiencing a declining utility and that it is "bad for employers," as well as employees. (Dannin, 2007, p. 5). As if that's not enough, work place expectations betray the fondest hopes of any ardent disciple using the "free market" system to defend at-will.

A market economy presumes that both sides to bargains have adequate information for making thoughtful, rational decisions. A corollary holds that the more imperfect the information, the greater the market distortion. Recent studies demonstrate that a strong majority of discharged workers and those with work believe that the just cause standard prevails in employment law. The same studies concluded that "managerial employees were just as illinformed as anyone." (Moss, 2005-2006, p. 348). Ironically, the clearer the at-will concept is to employees, the greater the negative impact that it has on employee morale. Full, adequate information is imperative for an efficient market economy, but in this instance, full information is corrosive to that desired efficiency. Legal theory and practice fares no better under the at-will regime and its multiple exceptions.

\section{At-Will Undermines Law's Hoped-For Predictability}

The study of law, Oliver Wendell Holmes wrote late in the nineteenth century, is not "a mystery but a well known profession." (Holmes, 1897, p. 457). The purpose for studying law, he continued, was to predict how public force would be used through the courts. Since courts bring the force of the state to enforce law and sanction its violations, it's important to know in advance law's path. The thousands of reports, the expanding numbers of treatises aim at "prophecies of what the courts will do in fact, and nothing more pretentious ..." When law works, legal principles form "a thoroughly connected system." (Holmes, 1897, p. 458). Nearly a century later, a recent commentator notes that court decisions create a "framework and thereby declares them to have some coherence." Further, he notes that "This coherence in the common law is internal to the system." (Schwab, 1993-1994, p. 61.)

If law's predictability and a coherent system is a key objective of law, it follows that at-will and its exceptions fall at the extreme opposite end of the legal spectrum. They are "full of holes," (Schwab, 1993-1994, 8), it's undergoing "increasing incoherence" (Moss, 2005-2006, p. 295) with a "mixed bag" (McGuinness, 2000-2001, p. 246) of decisions. Understanding requires "penetrating doctrinal camouflage" (Peck, 1991, p. 719) that attends atwill's current status. Two examples illustrate the lack of coherence and using different legal standards from laws "mixed bag" of doctrines. First, "States haphazardly adopt some proposed exceptions while rejecting others . . . More oddly, states cite the same rationales to adopt and reject opposite sets of exceptions."(Moss, 2005-2006, p. 301; emphasis in the original. Moss uses examples from New York and Wisconsin as examples of states that use legal rationales in conflicting ways.)

Additionally, if there are no sanctions for violating law, there is no law. However, dedication to protecting at-will protects illegal action. The Florida Supreme Court's loyalty to at-will in its original form "places a premium on unlawful employer conduct by failing to sanction employers for discharging employees who refuse to commit unlawful acts. As a result, employers use the doctrine as "leverage to violate federal and state laws with impunity." (De Nigria, 1991-1992. p. 1122). Pennsylvania courts are equally complicit in refusing to sanction illegal employer acts. (Dannin, 2007, 10-13.)

The negative baggage that attends at-will as the default standard for the majority of American workers leads commentators to call for its rejection. Deborah Ballam, one of the most careful and meticulous students of atwill's origins and exceptions predicted the doctrine's "impending death." (Ballam, 2000, p. 653). In assessing its future she concluded that "The future of employment at-will . . . is that it has no future." (Ballam, 2000, p. 687). Ending at-will through state enactments would be an important development, but would create a patch-work of state law to govern employment, a major component in the nation's interstate commerce. While it's impossible to divine the future, it's possible to find established precedent for national legislative action to end at-will and create national norms. 


\section{Rationale for a National Just Cause Standard Exists}

The rationale for a national just cause standard has existed for decades, and is particularly linked to the evolution of corporations - in particular with balancing corporate power with their social and economic utility in the nation's life. After decades of sometimes bitter debate, the modern corporate structure won grudging legitimacy in American political and economic life in the middle decades of the nineteenth century. (Hurst, 1970). However, during the Great Depression of the 1930s, corporations lost their earlier acceptance. It seemed imperative to impose new limits on their power.

Offsetting collective management with collective labor became a hallmark response to corporate power. Decades earlier the "visible hand of management" had displaced the so-called "invisible hand" of the market. (Chandler, 1977). During the 1930s, whether accurately or inaccurately, Congress concluded that the power of management's visible hand needed limits imposed by collective labor to offset collective management. Collective bargaining offset the imbalance in labor-management relations. An analogous calculus fits the just cause standard for terminating employment for non-union employees and helps remedy the baggage that attended at-will exceptions.

Employers and employees form contracts based on each party's reasonable expectations. Each has a just cause, whether making products to delivering services, on the one hand, to making a living, supporting a family and becoming responsible citizens on the other. Each party is a free agent, motivated by their respective ambitions and hopes; each justifiably relies on the other in achieving their hopes. One party's just cause for forming the contract balances the other party's just cause, which corrects the sham of mutuality of at-will. Each has reasonable expectations upon which they rely. Since the "reliance interest" (Fuller \& Perdue, 1936-1937) is a core contract value, the balance of reliance interests displaces the asymmetrical power imbalance of at-will. The employee's welfare conduces to the reciprocal welfare of the employer in conformity with the Constitution's general welfare clauses. (Preamble; Section 8, Cl.1)

Additionally, government's imprimatur of corporate approval and protection would extend to employees on a more equitable basis. Corporate charters empower organizations with a grant from government, afford limited liabilities to stockholders, but accord no comparable legal protection to employees within the corporation structure. Just cause termination redresses that imbalance, at least to some extent.

Upon showing just cause, employees could be terminated. Managers and employers have or can develop the evidence if there is a basis for termination, but are prohibited from terminating employees on a whim, for just any reason or a bad reason. A national standard of just cause would eliminate confusing and conflicting rules that would likely result from state-created standards. A national standard would put employers, employees, attorneys and other interested parties on notice. They would have access to the indispensable information necessary to know the path of the law. In addition to neutralizing, at least in part if not completely, at-will and its baggage, just cause serves other vital social and economic values.

New Deal policy makers concluded that a serious imbalance between production and income was a root cause of the depression. Inventories piled up, but the nation's purchasing power had been seriously compromised. A core policy of New Deal legislation was to increase purchasing power. The extent to which New Deal policies succeeded is ground for legitimate discussion. However, it's clear that searching the balance between production economics and income economics has been central to American economic policy since the 1930s. At first blush the 1942 Supreme Court case of Wickard v. Filburn seems eminently forgettable, but has as much relevance for the new century as it did in the early ' 40 s.

Under the Agricultural Adjust Act of 1938, Filburn an Ohio farmer had been allotted 11.1 acres if wheat, but he sowed 23 acres. Because of his violation of the 1938 enactment, the Department of Agriculture fined him $\$ 117.11$ for the excess wheat. Filburn argued that he shouldn't have to pay the fine since he consumed all of the wheat on his farm, so that none of it went into an already saturated market. However, Justice Robert Jackson, writing for the court, found against him. Jackson reasoned that Filburn bypassed the wheat market by consuming the excess wheat on his farm instead of going into the market to buy it. Jackson conceded that Filburn's excess production "may be trivia by itself . . ." However, he continued, the impact of aggregating production from excess 
acreage from "many others similarly situated is far from trivial," and could have a "substantial" impact on interstate commerce. (Wickard v. Filburn, 1942, pp. 127 \& 125). Jackson's rationale applies to at-will employees with even greater force than to wheat production.

It's hard to imagine that any reasonable person would insist that the annual loss of jobs from between 200,000 and 300,000 thousand employees is not substantial, and might even agree that the word "substantial" is seriously anemic in describing the true impact. When other considerations linked with the loss employment, such as the dashed expectations justifiably relied upon, disrupted family lives, creation of suspicion at the work place, where employees might wonder if they're next, and even disruption of communities, it becomes almost impossible to give the impact easy or accurate characterization. The impact of excess wheat production pales by comparison, both in human and economic terms to the job losses. The one is a mole-hill, the other a towering mountain. If controlling wheat production merits national regulation, by comparison arbitrary dismissals command regulation. The method for that regulation, through contract, is entrenched in American policy, practice and law.

Parties to a contract always have the first word, "but do not necessarily have the last word" on the contract's terms. Contracts have three parties involved since society keeps "company" with contracts. (Havighurst, 1961, p. 10). Parties to contracts set the initial terms, but whether society through its legal system will enforce the terms, modify or completely reject them depends on the company society keeps with contracts. The legal system attends contracts through one of three methods. First, through legislative and judicial action, specific terms are proscribed, made illegal, such as contracts in violation of public policy. Civil rights, anti-discrimination and antimonopoly legislation follow this tract. Second, contracts are required to include specific terms, such as workers compensation, minimum wage and maximum hours legislation. Third, and especially relevant for at-will issues, through legislative and judicial action, society uses the legal system to regulate the process by which parties create contracts, such as allowing the innocent party to a contract induced by fraud to have the contract enforced or to avoid it. The National Labor Relations Act of 1935, primarily a process statute, creates precedent suited to at-will issues.

Under the act the labor board can neither impose terms on the bargaining parties nor reject terms they agree upon. Its sole authority is to prevent the parties from committing unfair labor practices and to oversee the process by which bargaining units form, with limited powers to police the bargaining process. A just cause act to end at-will would regulate an analogous process, with a difference. Instead of focusing on the process by which employers and employees create contracts, it would exercise regulatory authority to assure a fair process for ending contracts. Overtime, the labor board found practices that were unfair labor practices; comparably regulations for ending contracts would develop just causes for their termination. The "company" the regulation keeps would be on process, not terms.

\section{CONCLUSION}

The assessment for the future of at-will "is that it has no future" (Ballam, 2000, p. 687) seems to be a sound judgment, even though its demise might be years off. Within limits its history tracks that of other major legal traditions that accompanied its evolution in American life; slave law, followed by the Jim Crow era of post-Civil War America, and the law of coverture were essentially unscathed for generations. As different as these legal traditions were, they reflect a body of law that permitted one group to exercise varying degrees of control over other groups. Although slavery ended with the $13^{\text {th }}$ Amendment of 1865 , it afforded masters unlimited control over their slave laborers. Its Jim Crow replacement continued to give white Americans firm control over their black counterparts. Coverture gave married men legal authority over most of their wives' activities; similarly, at-will gave employers virtually unlimited control over their employees on the job site.

Rejection of these legal traditions followed an analogous pattern, which meant that slavery, the system with the greatest degree of control ended first, followed by the Jim Crow system and coverture. Before Jim Crow's demise in 1954 in Brown v. Board, it was in retreat, particularly during the preceding decade. Although remnants of Jim Crow and coverture lived beyond the 1964 Civil Rights Act, their careers in American life were ending. By comparison, at-will, which afforded control primarily in the work place, limps on as the default system, but one riddled with exceptions. On the one hand, employers who apply at-will in its original form of dismissal for any reason, for no reason or for a bad reason will likely come to regret their action, but on the other hand, employees and 
critics of at-will continue to wonder when at-will will becomes become a legacy of the past, part of the American dust bin that includes slavery, Jim Crow and coverture.

By way of conclusion, the authors offer the opinion that in today's multi-state and international business environment where keeping track of exceptions to employment-at-will could be time-consuming and costly, it is best for organizations to behave as if "just cause" is the law of the land. This perspective will avoid error and potential law suits, but, more importantly, establish that the employer is willing and determined to do the right thing by assuring justice and due process in the workplace. This culture of fair play can be a crucial part of establishing a reputation as an employer-of-choice.

\section{AUTHOR INFORMATION}

Dr. Jane Whitney Gibson is a Professor of Management at Nova Southeastern University where she teaches undergraduate and graduate classes in human resources, organizational behavior, management, and leadership. Gibson is the Editor of The Journal of Applied Management and Entrepreneurship and the author of multiple textbooks and articles in the field. She is active in the Academy of Management and her current research interests include online learning and comparative generational values.

Dr. Lester Lindley, J.D, Ph.D. is an Adjunct Professor of Business Law and Management at Nova Southeastern. He's taught business law, constitutional and legal history since the 1980s, and has published books and articles in each of those three disciplines. In addition to his academic career, he practiced law in the Chicago area on a parttime basis for three years. His research interests continue to be the intersection of law and public policy, placed in their historical context.

\section{REFERENCES}

1. Anonymous. (October 2007). How at-will employment is changing. HR Focus 84(10), 1, 11, 13-15.

2. Abraham, S. (2008). The Arizona employment protection act: Another 'wrongful discharge statute' that benefits employers? Employee Rights \& Employment Policy Journal. 12(1), 105-129.

3. Atwood, C. (March 1991) Don’t be a sitting duck, HR Magazine, 96.

4. Ballam, D. (1995-96). The development of the employment at-will rule revisited: A challenge to its origins as based in the development of advanced capitalism. Hofstra Law Journal (13), 75-107.

5. Ballam, D. (1996). Exploding the original myth regarding employment-at-will: The true origins of the doctrine. Berkeley Journal of Employment and Labor Law, (17), 91-130.

6. Ballam, D. (2000). Employment-at-will: The impending death of a doctrine. American Business Law Journal, 37(4) pp. 653-687.

7. Benjes, S. \& MacDonald, E. (September 12-25, 2008). Ballot measure could prove "death knell" for employment at will in Colorado. Boulder County Business Report, 27(19), 29A.

8. Bird, R. (2004-2005). Rethinking wrongful discharge: A continuum approach. University of Cincinnati Law Review, (73), 517-79.

9. Blades, L. (1967). Employment at will vs. individual freedom: On limiting the abusive exercise of employer power. Columbia Law Review. (67), 1404-1435.

10. Callahan, E. (1990). Employment at will: The relationship between societal expectations and the law. American Business Law Journal, 28(3), 455-482.

11. Carnegie, A. (April 1886). An employer's view of the labor question. Forum. (1), 114-115.

12. Cavico, F. (Winter/Spring, 1992). Employment at will and public policy. Akron Law Review. 25(3\&4), 497-546.

13. Center for Education \& Employment Law. (2009) Deskbook of employment law $17^{\text {th }}$ ed. Malvern, PA.

14. Chandler, A. (1977). The visible hand: The managerial revolution in American business. Cambridge: Harvard University Press.

15. Cottone, E. (2001-2002). Employee protection from unjust discharge: A proposal for judicial reversal of the terminable-at-will doctrine, Santa Clara Law Review. (42), 1259-90.

16. Dannin, E. (Spring, 2007). Why at-will employment is bad for employers and just cause is good for them. Labor Law Journal 58(1), 5-16. 
17. De Nigria, S. (1991-1992). The public policy exception: the need to reform Florida's at-will employment doctrine after Jarvinen v. HCA Allied Clinical Laboratories and Bellamy v. Holcomb. Nova Law Review. (16), 1079-1123.

18. Employment Act of 1946, Public Law 304, $79^{\text {th }}$ Congress.

19. Fuller, L. \& Perdue, W. (1936-1937). The reliance interest in contract damages: 1. Yale Law Review, 46, 52-96.

20. Gertz, S. (2008). At-will employment: Origins, applications, exceptions and expansions in the public service. International Journal of Public Administration 31(5), 489-514.

21. Gorczyca, B. (August 11, 2006). At-will employment still has regulations. The State Journal. 22(31), 19.

22. Havighurst, H. C. (1961). The nature of private contract. Evanston, IL: Northwestern University Press. Holmes, O. (March 1897) The path of the law. Harvard Law Review, (10), 457-78.

Hurst, J. (1970). The legitimacy of the business corporation. Charlottesville: University Press of Virginia. Lichtenstein, S. \& Darrow, J. (March 2008). At-will employment: A right to blog or a right to terminate? Journal of Internet Law, 11(9), 1, 11-20.

26. Lynott, W. (June 1, 2008). How to steer clear of potential labor problems. Ophthalmology Times, 33(11), p. 36,38 .

27. McGuinness, J. (2000-2001). North Carolina's developing public policy wrongful discharge doctrine in the new millennium: Basic principles, causation \& proof of improper motive. Campbell Law Review, (23), 203-247.

28. Moss, S. (2005-2006). Where there's at-will, there are many ways: Redressing the increasing incoherence of employment at will. University of Pittsburgh Law Review, (67), 295-364.

29. Muhl, C. (January 2001). The employment-at-will doctrine: Three major exceptions. Monthly Labor Review, 3-11.

30. Peck, C. (1991). Penetrating doctrinal camouflage: Understanding the development of the law of wrongful discharge. Washington Law Review, (66), 719-773.

31. Proffitt, R. (April 2009). Just cause? Public Management, 91(3), 3.

32. Sentell, E. \& Robbins, R. (2008). Employment-at-will. Journal of Legal, Ethical, and Regulatory Issues. $11(1), 1-15$.

33. Schmidt, J. (1998). Free to work: Labor law, emancipation, and reconstruction, 1815-1880. Athens and London: University of Georgia Press, 1-92.

34. Schwab, S. (1993-1994). Life-cycle justice: Accommodating just cause and employment at will. Michigan Law Review. (92), 8-62.

35. Shales, A. (2007) The forgotten man: A new history of the Great Depression. NY: HarperCollins.

36. Slater, J. (2007). The "American rule" that swallows the exceptions. Employee Rights \& Employment Policy Journal. (11), 53-110.

37. Stone, K. (March, 2007). Revisiting the at-will employment doctrine: Imposed terms, implied terms, and the normative world of the workplace. Industrial Law Journal, 36(1), 84-95.

38. Suk, J. (October 2007). Discrimination at will: Job security protections and equal employment opportunity in conflict. Stanford Law Review, 60(1), 73-113.

39. Walsh, D. and Schwarz, J. State common law wrongful discharge doctrines: Up-date, refinement, and rationales. American Business Law Journal, 37(4), 646-89.

40. Zachary, M. (September 2008). A legal termination. SuperVision 69(9), 22-25

\section{Cases and Statutes}

1. Agricultural Adjustment Act. (1938). Statutes at Large, 31(30).

2. Brown v. Board of Education of Topeka, 347 U.S. 482 (1954)

3. Franklin Mining v. Harris, 24 Mich. 11, (1871).

4. $\quad$ Mitford v. deLasala, 666 P.2d 1000, (1983).

5. Payne v. Western \& Atlantic RR Co., 81 Tenn. 507, (1884).

6. Petermann v. International Brotherhood of Teamsters, 344, P.2d 25, (1959).

7. Pugh v. See's Candies, 116 Cal. App.3d. 311 (1981)

8. Stark v. Parker, 19 Mass. 267, (1824).

9. Wagenseller v. Scottsdale Memorial Hospital, 710 P.2d, 1025 (1985).

10. Wickard v. Filburn, 317 U.S. 111(1942). 